\title{
Pemanfaatan Media Sosial Efektif Dalam Melakukan Upaya Promosi Kesehatan
}

\author{
Erina Dewi Rianti, Muhammad ali sodik \\ IIK Strada Indonesia \\ erynadewy@gmail.com, alisodik2012@gmail.com
}

\begin{abstract}
Abstrak
Kebutuhan informasi kesehatan yang akurat dan terkini semakin dibutuhkan seiring perkembangan teknologi informasi. Media sosial telah menunjukkan perannya dalam upaya promosi kesehatan di dunia. Jenis media sosial yang digunakan dan kelemahannya peran profesional bidang kesehatan melakukan promosi kesehatan berbasis media sosial.

Hasil Penelusuran mengungkapkan media sosial berkontibusi positif terhadap upaya promosi kesehatan, namun beberapa kelemahan antara lain: kurangnya penjangkauan terhadap audien pasif, informasi palsu dan tidak akurat, kurangnya interaksi dengan audien, keterbatasan kemampuan profesional kesehatan memanfaatkan media sosial sehingga tidak menjamin keberlanjutan program. Profesional bidang kesehatan perlu merancang model promosi kesehatan berbasis media sosial dengan mengintegrasikan media sosial dengan strategi promosi kesehatan serta strategi komunikasi kesehatan.
\end{abstract}

\section{Kata kunci: Media Sosial, Promosi Kesehatan.}

\section{Latar Belakang}

Perkembangan penyakit merupakan hal yang hampir seimbang bahkan lebih dibandingkan dengan tingkat pertumbuhan penduduk di Indonesia, setiap detik penduduk di Indonesia terkena penyakit yang belum tentu kita temukan obatnya, setiap individu manusia baru merasakan dirinya mengalami penyakit apabila mengalami gejala-gejala yang mulai mengganggu, tindakan yang diambil salah satunya adalah dokter dan Rumah Sakit. Peran Rumah Sakit sebagai salah satu institusi kesehatan belum memadai dalam publikasi informasi tentang kesehatan, meskipun tindakan rumah sakit dalam mempromosikan penyakit dan penanggulangannya sudah dilakukan. Banyak faktor yang tidak diketahui akibat pemberitahuan, publikasi atau segala informasi penyuluhan yang diberikan oleh praktisi atau institusi kesehatan. 
Seperti halnya penyakit, perkembangan teknologi telah mencapai tingkatan siapa saja,kapan saja dan dimana saja dapat memproleh informasi dengan sangat cepat dan murah. Salah satu media penyampaian informasi secara cepat dengan teknologi merupakan salah satu kehandalan internet sebagai fenomena teknologi, untuk penggunaan media internet. Kebutuhan akan informasi yang akurat, tepat, dan terkini semakin dibutuhkan seiring dengan perkembangan teknologi informasi yang sangat pesat. Hal ini mendorong masyarakat dan instansi untuk memanfaatkan teknologi informasi tersebut. Informasi yang beragam terlepas dari sifatnya yang dapat bernilai positif atau negatif akan mempengaruhi timbulnya suatu masalah, khususnya masalah kesehatan. Penataan informasi yang dilakukan secara teratur, jelas, tepat, dan cepat serta dapat disajikan dalam sebuah laporan tentunya sangat mendukung kelancaran kegiatan operasional organisasi dan pengambilan keputusan yang tepat. Sekarang ini, website tidak hanya diakses dengan menggunakan browser didesktop, namun juga di akses di tablet ataupun smartphone. Dengan demikian perlu di analisis bagaimana peluang untuk melakukan upaya perubahan perilaku melalui pendidikan kesehatan dan promosi kesehatan dengan menggunakan media online.

\section{Kasus/Masalah}

1. Bagaimana urgensi pemanfaatan media sosial dalam bidang promosi kesehatan?

2. Apa saja jenis media sosial yang digunakan selama ini dan apa kelemahanya?

3. Bagaimana peran profesional dalam bidang kesehatan melakukan promosi kesehatan berbasis media sosial?

\section{Tinjauan pustaka}

Dalam Kamus Besar Bahasa Indonesia dalam Jaringan , pengertian "media" adalah "alat (sarana) komunikasi, seperti koran, majalah, radio, televisi, film, poster, dan spanduk, yang terletak di antara dua pihak (orang, golongan, dan sebagainya)". Sedang "sosial" diartikan sebagai "hal yang berkenaan dengan masyarakat". Berdasarkan arti dua kata dasar tersebut, dapat dikatakan bahwa "media sosial" adalah "sebuah sarana komunikasi dalam suatu masyarakat".

Menurut 'What is?' , media sosial adalah "saluran komunikasi online kolektif yang didedikasikan untuk input, interaksi, berbagi konten, dan kolaborasi berbasis masyarakat". Situs web dan aplikasi yang didedikasikan untuk forum, microblogging, jaringan sosial, bookmark sosial, kurasi sosial, dan wiki adalah salah satu jenis media sosial. 
Media sosial dalam ranah kekinian merupakan sebuah era baru dalam hal sarana komunikasi yang semakin intensif dalam pemanfaatan kemajuan teknologi. Teknologi berbasis Web 2.0 memungkinkan tumbuhnya masyarakat baru yang semu, atau dalam dunia baru tersebut biasa disebut sebagai dunia maya.

Mau tidak mau semua bidang harus mengikuti trend ini bila tidak ingin ketinggalan zaman. Bidang kesehatan juga tidak bisa terelakkan, mau tidak mau, harus ikut arus perubahan yang terasa sangat cepat ini, terutama bidang kesehatan yang berhubungan dengan masalah komunikasi atau penyampaian informasi pada khalayak ramai. Beberapa studi atau penelitian yang telah dilakukan tentang kontribusi media sosial untuk bidang kesehatan telah banyak dilakukan, meski di dalam negeri sendiri hal ini masih belum menjadi topik kajian yang menarik. Penelitian dan kajian tersebut banyak mengupas tentang potensi media sosial, ketersediaan informasi, dukungan untuk pasien penyakit tertentu, efektivitasnya dalam penyampaian informasi, ataupun diskursus tentang suatu topik tertentu.

\section{Pembahasan}

A. Promosi Kesehatan dan Urgensinya Menggunakan Media Sosial

Menurut WHO, promosi kesehatan adalah proses mengupayakan individu -individu dan masyarakat untuk meningkatkan kemampuan mereka mengandalkan faktor-faktor yang mempengaruhi kesehatan sehingga dapat meningkatkan derajat kesehatannya. Bertolak dari pengertian yang dirumuskan WHO, Indonesia merumuskan pengertian promosi kesehatan adalah upaya untuk meningkatkan kemampuan masyarakat melalui pembelajaran dari, oleh, untuk dan bersama masyarakat agar mereka dapat menolong diri nya sendiri (mandiri) serta mengembangkan kegiatan bersumber daya masyarakat sesuai sosial budaya setempat dan didukung oleh kebijakan publik yang berwawasana kesehatan. promosi kesehatan adalah upaya yang dilakukan terhadap masyarakat sehingga mereka mau dan mampu untuk memelihara dan meningkatkan kesehatan mereka sendiri. Menggunakan media sosial dapat meningkatkan akses masyarakat terhadap informasi kesehatan, serta mempromosikan perubahan perilaku yang positif, dengan demikian media sosial dapat berkolaborasi dan melengkapi promosi kesehatan yang selama ini masih konvensional. Media sosial dapat menjadi alat yang unggul dengan jangkauan dan interaktivitas luas. Beberapa bukti empiris menemukan hal menarik menggunakan media sosial untuk intervensi pencegahan penyakit seperti penghentian perilak merokok melalui Tweet dan situs kesehatan, video youtube tentang kanker, peningkatan pengetahuan remaja tentang kesehatan reproduksi, pengetahuan pasien mengenai diabetes dan pemahaman mengenai kebugaran dan aktifitas fisik melalui 
facebook. Situs jejaring sosial lainnya yang banyak dikunjungi oleh pencari informasi terkait kesehatan adalah melalui web yang memuat informasi tentang kesehatan seksual, diet sehat, kesehatan ibu hamil, kesehatan reproduksi remaja putri. Kesehatan komunitas klinis di rumah sakit yang berhasil meningkatkan citra rumah sakit yang memanfaatkan media online yang berisi konten tentang gaya hidup sehat bagi pasien, kondisi kedaruratan dalam bidang kesehatan. Promosi kesehatan melalui online juga bisa dapat di aplikasikan ditempat kerja, dimana informasi umumnya adalah tentang kesehatan karyawan.

Teknologi berupa media sosial memfasilitasi pengetahuan masyarakat yang lebih baik tentang penyakit dan pencegahannya, penggunaan layanan kesehatan yang lebih baik, lebih patuh terhadap pengobatan dan partisipasi dalam keputusan kesehatan [38], peningkatan dukungan sosial serta berbagi dukungan kepada orang lain sehingga masyarakat mampu secara mandiri menyebarluaskan pengalaman positif mereka tentang perubahan perilaku yang lebih sehat, perubahan tubuh, efek samping penyakit serta dampak positif dari menerapkan gaya hidup sehat. Secara keseluruhan,berdasarkan studi literatur menunjukkan media sosial berkontribusi positif terhadap pencapaian tujuan dari promosi kesehatan, sehingga para profesional bidang kesehatan diharapkan mampu berkolaborasi dan mengintegrasikan media sosial dengan strategi promosi kesehatan.

\section{B. Jenis media sosial dan kelemahanya}

Era digital yang dikenal dengan Web 2.0 atau Health 2.0 atau Medicine 2.0 menjadikan masyarakat sehat dan pasien lebih mengandalkan Internet daripada dokter sebagai sumber informasi perawatan kesehatan. Situs web media sosial yang populer terbukti efektif dan ampuh untuk menyebarluaskan informasi kesehatan, mendukung upaya promosi kesehatan dan dapat ditelusuri secara online seperti YouTube, Facebook, MySpace, Twitter, Tiktok, Instagram dan Second Life. serta image sharing, mobile technology dan blog. Namun beberapa kelemahan antara lain: kurangnya penjangkauan terhadap audien pasif, informasi palsu dan tidak akurat, kurangnya interaksi dengan audien, keterbatasan kemampuan profesional kesehatan memanfaatkan media sosial sehingga tidak menjamin keberlanjutan program. Profesional bidang kesehatan perlu merancang model promosi kesehatan berbasis media sosial dengan mengintegrasikan media sosial dengan strategi promosi kesehatan serta strategi komunikasi kesehatan.

C. Peran profesional dalam bidang kesehatan melakukan promosi kesehatan berbasis media Sosial 
Perubahan perilaku kesehatan yang tidak menurun secara signifikan merupakanpandangan pesismis untuk mengadopsi potensi media sosial untuk promosi kesehatan. Pandangan tersebut perlu dimimalisir dengan meningkatkan peranprofesional bidang kesehatan dalam meningkatkan kualiatas promosi kesehatan berbasis media. Peran profesional tersebut antara lain:

1. Adopsi konsep media sosial yang telah berhasil di bidang bisnis. Saran memanfaatkan media sosial tersebut adalah identifikasi media dengan hati-hati, pilih aplikasi atau buat sendiri, pastikan keselarasan aktifitas dimedia sosial, integrasi rencana media dan akses untuk semua. Kesuksesan penerapan aplikasi tersebut dengan meluangkan waktu untuk meninjau interaksi/percakapan dan mendedikasikan waktu untuk menanggapi tanggapan audien.

2. Menggabungkan media sosial dengan strategi pemasaran sosial dengan 4 langkah jelaskan audien, tuliskan tujuan untuk terlibat dengan audien, buat garis besar strategi khusus untuk melibatkan dan pilih teknologi.

3. Mengembangkan rencana komunikasi strategis dengan menggabungkan media sosial dengan praktek dilapangan untuk memperluas jangkauan dan mendorong interaktivitas dan keterlibatan.

4. Profesional kesehatan perlu mempertimbangkan dampak terbaik dan terburuk dari konten yang mereka sampaikan di media sosial serta mempertimbangkan sinergi antara media sosial dan promosi kesehatan.

5. Organisasi dan praktisi promosi kesehatan harus dapat mencocokkan kebutuhan program dengan hasil yang diberikan oleh media sosial dengan melakukan evaluasi secara komprehensif, dengan kerangka kerja evaluasi proses dan evaluasi dampak.

6. Mengembangkan intervensi dengan membentuk tim multidisiplin, menjamin ketersediaan sumber daya untuk mempertahankan kehadiran online serta interaksi dua arah merupakan fitur baru promosi kesehatan dengan media sosial.

7. Mengidentifikasi dan memilih konten dengan isu-isu terkini dengan mempertimbangkan berbagai pemangku kepentingan.

8. Profesional kesehatan dapat mengadopsi 3 cara penggunaan internet untuk meningkatkan kesehatan masyarakat:

1) menggunakan format wiki untuk pengetahuan dasar seperti "wikihealth" untuk komunitas yang membutuhkan informasi/pengetahuan,

2) membentuk organisator komunitas seperti model MySpace, 
3) menggunakan blog untuk bertukar informasi.

9. Memaksimalkan paparan informasi dengan basis bukti yang kuat, dengan mempertimbangkan konten relevan untuk audien yang tepat atau bahkan berbeda serta memperjelas peran profesional dalam memfasilitasi media sosial.

\section{Kesimpulan}

Kebutuhan akan informasi yang akurat, tepat, dan terkini semakin dibutuhkan seiring dengan perkembangan teknologi informasi yang sangat pesat terutama di bidang kesehatan. Media sosial melalui internet memiliki potensi besar untuk melakukan promosi kesehatan dan intervensi kesehatan lainnya, dan lebih mudah untuk menyentuh sasaran pada setiap levelnya. Bukti empiris menunjukkan pemanfaatan media sosial efektif dalam melakukan upaya promosi kesehatan dengan tujuan meningkatkan pemahaman dan memberi dukungan kepada masyarakat untuk berperilaku sehat, namun tidak dapat dipungkiri, dibalik kesuksesan media tersebut terdapat beberapa kelemahan. Solusi terhadap kelemahan tersebut dengan meningkatkan peran profesional bidang kesehatan dalam mengelola promosi kesehatan berbasis media sosial, sehingga informasi lebih berkualitas. Profesional kesehatan dapat melakukan langkah-langkah berikut: mengidentifikasi audien, memilih konten yang tepat, memilih strategi yang dapat diadopsi dari bidang lain seperti bidang bisnis, memberikan informasi berbasis data yang akurat dan terkini, meningkatkan partisipasi audien dan penyedia layanan, melakukan monitoring dan evaluasi guna memastikan program promosi berhasil dan berkelanjutan secara online. 


\section{Daftar Pustaka}

1) Barakhsanova, E.A et. al (2016) Internet Access and Youth of Yakutia Awareness on the Health-Promotion Factor. International Journal Of Environmental \& Science Education Vol.11, No.18, 11477-11484

2) Wangberg, Silje C. et.al (2007) Relations between Internet use, socio-economic status (SES), social support and subjective health. Health Promotion International, Vol. 23 No. 1 doi:10.1093/heapro/dam039 Advance Access published 13 December 2007

3) Levac \& Sullivan (2018) Interactive social media interventions for health behaviour change, health outcomes, and health equity in the adult population Cochrane Database of Systematic Reviews 2018, Issue 2. Art. No.: CD012932: doi:10.1002 /14651858 .CD012932. www.cochranelibrary.com

4) Shabbir, SA., Luis Fernandez-Luque, Wen-Shan Jian, YuChuan Li; Steven Crain, Min-Huei Hsu, Yao-Chin Wang, Dorjsuren Khandregzen, Enkhzaya Chuluunbaatar, Phung Anh Nguyen, Der-Ming Liou. Misleading Health-Related Information Promoted Through Video-Based. Social Media: Anorexia on YouTube. Journal of Medical Internet Research. Volume 15 (2): e30: 2013 YouTube, 2009. Sharing YouTube Videos. YouTube, 17 Januari 2009. 